Проф. др Снежана Милосављевић Милић

Универзитет у Нишу

Филозофски факултет

821.163.41.09-14 Кочић П. https://doi.org/10.18485/ai_kocic.2017.ch9

snezana.milosavljevic.milic@filfak.ni.ac.rs

\title{
ПОЕТИКА ЛИРСКЕ ПРОЗЕ ПЕТРА КОЧИЋА
}

У раду се разматрају поетички поступци у краћим прозним текстовима које је Петар Кочић објавио у часопису Срйски књижевни іласник и у листу Политиика у току 1903. и 1904. године: Јелике и оморике, Кроз маглу, Кроз свјетилости, У маїли, Пјесма младостии, Јајце. Унутар поетичког контекста симболистичке прозе, поменути текстови су анализирани као хетерогени жанр у коме се преплићу лирски и епски елементи. Посебно су разматране песничке слике као сложени имагинативи који настају у садејству поетских и наративних стратегија. Тумачење приповедног потенцијала и догађајности показало је да је Кочић из фолклорне, романтичарске и реалистичке традиције често преузимао поједине топосе и сижее, док је на плану фигуративног исказа и наративне редукције најављивао или антиципирао модернистичке поетичке стратегије.

Кључне речи: песма у проза, модернизам, симболизам, наратив, песничка слика.

За Кочићев књижевни опус Јован Дучић је рекао да је „мало, али златно дело“, што је оцена која унеколико подсећа на општеприхваћени критички став поводом непосредног Кочићевог претходника, Лазе Лазаревића. У том „малом делу“, заступљени су готово сви прозни жанрови, осим романа: „приповетка, новелета, скица, песма у прози“ (Вучковић 1990: 335), као и драмски жанр. 
Упркос овој варијабилности, у књижевноисторијским прегледима Кочићевог опуса налазе се запажања о преовлађујућој структури (Вучковић 1990), стилској уједначености (Палавестра 2013, Деретић 1983), заједничком тону (песимизам, борбеност).

Када се, међутим, баци само летимичан поглед на рану рецепцију Кочићевог дела која долази од његових савременика, уочава се разуђеност ставова, противуречност и непрецизност или недореченост у проценама. Притом су и неке критичке тврдње данас тешко одрживе, док су неке по инерцији прихватане и преношене, иако их пажљивија анализа текстова демантује. Стиче се, такође и утисак да су рани Кочићеви читаоци били донекле збуњени, можда и самом унутрашњом сложеношћу његове прозе. Тако, на пример, Јован Скерлић, пишући о „лирским реалистима“ поводом прве Кочићеве збирке $C$ йланине и исйоg йланине истиче „количину живота кондензованог у једном делу“ (Скерлић 2000: 137), да би поводом треће књиге констатовао уплив меланхолије и песимизма.

И импресија Бранка Лазаревића, као да само површински захвата поједине утиске критичара, или макар оне почетне. Индикативан је Лазаревићев став да је Кочић: „у првим стварима јако оптимистички расположен и према људима и према стварима“" (Лазаревић 2003: 69), или, да се „осећање природе“ у првој књизи само наслућивало после чега је дошло једно оптимистички, свеже, светло, добротворно, животворно, пантеистичко осећање природе (Лазаревић 2003: 67).

Методолошки еклектицизам и неиздиференцираност теоријског предлошка, као одлика критичког дискурса, може бити оправдање и за недовољно аргументоване синтетичке оцене у раној рецепцији Кочића: лиризам, искреност, свежина, кристалан језик, течан и занимљив дијалог, местимично поетски стил (Скерлић 2000: 142). Уосталом, са Скерлићем се не слаже ни Р. Вучковић у погледу два 
закључка о Кочићевој прози који се односе на постојање импресионистичког сликарског стила, те нежних прелива и светлих тонова. Упоређујући Кочића са импресионистичким сликарима Монеом и Писароом, Скерлић пишчеву усредсређеност на „сликарски пејзаж“ тумачи као „књишку склоност“. Отуд текстове Кроз маіллу и „Кроз свейлоси" сагледава као два импресионистичка пандана „сликар(а) који у својим изгубљеним тренуцима пише новеле“ (Скерлић 2000: 139). Насупрот колоритности, Вучковић уочава симболичку дисхармонију и монументалну пластику, те контраст светлог и тамног који прати „опозицију живот-смрт“ на којој почива „бинарна схема“ Кочићевих прозних жанрова (Вучковић 1990: 336, 338).

Антитетичких закључака нису лишена ни новија читања Кочићеве ране прозе. Довољно је упоредити Деретићев став о Кочићу као „лирском реалисти“, „пејзажисти и колористи“ (Деретић 1983: 470) са оним Вучковићевим мишљењем које смо управо цитирали, или, са друге стране, Палавестрино уочавање Кочићеве „живе имагинације“ која је „сва у јасним сликама“ и „чврсто реалистичко опредељење“ (Палавестра 2013: 259), са општом оценом С. Пековић о „замагљеној слици света“ (1985: 548) карактеристичној за симболистичку српску прозу на почетку 20. века.

Не улазећи у овом тренутку у сложене разлоге амбивалентне рецепције, могли бисмо претпоставити да се један од разлога за опречна читања раног Кочића крио у новој прозној форми - поетској прози или, у устаљеним жанровским вокабуларом прихваћеном термину, песми у прози. Иако Кочић није био једини српски писац који ствара у овом жанру (поред својих савременика, Јована Дучића и Милутина Ускоковића), ${ }^{1}$ он је у естетском погледу надмашио друге. Насупрот извештаченој

1 Исцрпније о томе: Стојановић Пантовић: 2001. 
артифицијелности и књишком тону Дучића, Кочићеве песме у прози су, сложићемо се са Вучковићем, „поетски записи виђеног, доживљеног и непосредно казаног у ритмизираном прозном говору“" (Вучковић 1996: 336). Премда се овакав закључак асоцијативно може довести у везу са типичном реалистичком техником, Кочићеве песме у прози нису чисто миметичког карактера, као што нису ни чиста поезија или само лирска дела.

2.

Полазећи од чињенице да је „модернитет неког текста заснован на његовом историцитету“ (Улиг 2010: 99) тумачењу песме у прози мора се приступити најпре унутар њеног историјскопоетичког контекста који је непосредно повезан са поетичким правцем симболизмом. Док се у западноевропској књижевности појава симболизма повезује са истоименим манифестом Жана Мореаса из 1886. године, у српској књижевности његов почетак се подудара са „другом фазом европског симболизма“ (Палавестра 1985: 11) тако да гранични периоди обухватају, према Палавестри, последњу деценију 19. века и прве две деценије 20. века (1890-1920). Притом, истиче овај критичар, поменуте границе не треба узети у смислу строго ограниченог раздобља, како због његове развојне линије („пуна сезона, раносимболистичка и касносимболистичка фаза“), тако и услед унутрашњег поетичког херметизма.

„Српски симболизам није био ни школа ни покрет него сийне и форма йесничкої gуха; чак и у пуној сезони свога деловања и зрачења био је испуњен многобројним и различитим, па и супротним хтењима. Био је изразито синкретичан и синтетичан, противречан и дифузан, тако да су му се облици мешали а трагови могли установити и 
код претходника и међу далеким каснијим потомцима.“ (Палавестра 1985: 26)

Сагледану на фону општих карактеристика модернизма, као што су „жанровска неодређеност, криза репрезентације, фрагментарност" (Палавестра 1985), симболистичку прозу обележава у првом реду лиризација или поетизација прозе. На формалном плану овај поступак је видљив у фрагментаризацији прозне целине, појави асоцијативне и прозе тока свести и „губитку ауторитета приповедача“; жанровском херметизму манифестованом у „изостављању логичке и хронолошке везе међу деловима“, „радњи која губи на динамичности, тако да се сва пажња усмерава на стање и атмосферу“. На тематском плану јача интерес за „индивидуално насупрот општем и колективном“, за „личну мистику и (психолошко) фантастични свет“ док „интимистичка проза“ замењује „моралне и социјалне теме“ (Пековић 1985: 548-559). Већ овакво сумирање указује на то да се суштинска поетичка (и у ширем смислу културна) својства симболистичке прозе читају на подлози уже традиције или, прецизније, у опреци према претходном реалистичком раздобљу. То је можда и један од разлога што се репрезентативним и парадигматичним жанром овог периода сматра управо песма у прози. Овај жанр у доброј мери одражава „синкретизам симболизма“ чије кључно својство неки тумачи виде управо у Бодлеровом појму коресйондениије (Митровић 1985: 562).

У српској књижевнонаучној мисли у до сада најопсежнијој теоријској студији која се бави овом темом Б. Стојановић Пантовић, песма у прози се одређује као „прозни жанр са песничким одликама“ који је у српској књижевности с почетка 20. века био један од водећих жанрова. Повезујући је са доминацијом лирике као парадигме 
модерне поезије ${ }^{2}$ ауторка истиче њено лако прилагођавање лирско исповедном, симболичком и наративном садржају (Стојановић Пантовић 2001: 24).

Упркос одређеним терминолошким недоумицама, када није сасвим могуће разграничити семантички домен генеричких одређења йоейске йрозе, лирске иррозе, йесме у $\bar{u}$ рози, ириичие, једна се квалитативна компонента издваја као њихова differentia specifica. То је йесничка слика. Tрадиционално виђена као преовлађујуће лирско начело, песничка слика у симболистичкој прози носи сложена значења и вишеструке, чак и амбивалентне функције. Као природно исходиште фигуративног исказа (симбола), она је истовремено и стилска и генеричка и периодизацијска дистинктивна ознака. ${ }^{3}$

Према једној од дефиниција, симбол је стилска фигура која треба да покрене низ перцепција, веровања и емоционалних одговора тако што конкретно упућује на нешто апстарактно, а видљиво на оно што је невидљиво. „Simboličko se označavanje temelji na imaginacijskim konstantama, koje su dio kolektivnog iskustva skupine,

2 У погледу генезе Стојановић Пантовић зачетке песме у прози налази у енглеској и немачкој књижевности с краја 19. века. Постоје, међутим, и опречна схватања по којима се о овом облику жанровског херметизма може говорити већ поводом Библије као прве књиге лирске прозе. Ф. Грчевић сматра да је први Бодлер дао овом облику „квалитете парадоксалног лаконизма, епиграматичне заокружености и тематске актуелности омогућивши му тако да постане глобалом новог животног и књижевног сензибилитета којим доминирају људска растрзаност, меланхолија и неуроза" (Грчевић 1985: 514). П. Палавестра популаризацију песме у прози доводи у везу са ширењем слободног стиха (1985: 37).

3 Готово да нема тумача који поводом симболистичке прозе не

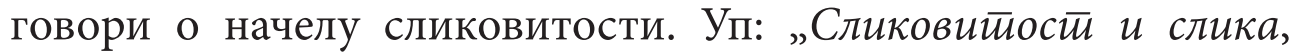
преузети од парнасоваца, мада осмишљених на други начин, према многим тумачењима представљају главне одлике симболистичког стила.“ (Палавестра 1985: 29). 
zajednice ili kulturnog kruga. U poeziji simbolizma, koja je izrazito subjektivna, aluzivna i tamna, autorski su simboli temelj lirskog prikazivanja“ (Багић 2012: 285). Три су обележја књижевног симбола: „dvostruko čitanje, motiviranost (simbol je izvedena figura koja se ostvaruje preko drugih figura) i polivalentnost“ (Багић 2012: 285). За интерпретацију песничке слике и жанра чији је она основни облик од пресудног значаја је приступ симболу као иконичком знаку „kada se naglašava karakter njegove veze sa objektom koji evocira motiviranost, sličnost, analogija“ (Багић 2012: 288).

Иконичку природу симбола у овом случају прихватамо заједно са критиком такозваног „сензуалистичког мита у тумачењу слике“ (Брајовић 2000: 173). Притом усвајамо становиште по коме су дистинктивна својства песничке слике: „аналогијска предикација, хетеротопија и фикционалност“ (Брајовић 2000). Према томе, ако је иманентно својство поетског сликовитог израза имаіинатиив (Брајовић 2000: 186), оправдано је поставити питање о (са)односу константивних (наративних) и имагинативних поетских исказа ${ }^{4}$ у контексту жанра песме у прози. У раду ово питање неће бити разматрано превасходно са теоријског аспекта, већ ће тежиште бити на тумачењу особитих поетичких карактеристика Кочићеве ране прозе у којој несумњиво постоји садејство нара-

4 За прецизнију елаборацију овог односа упућујемо на следећи цитат: „константивни и имагинативни поетски искази делују мање „аутономно“ него конвенционални природнојезички искази, односно, њихово међудејство је, може се рећи, наглашеније и узајамније него у непоетском изражавању. Па, као што

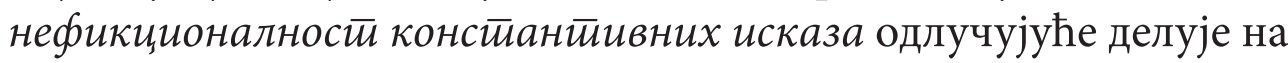
настајање свести о изотопији (кон)текста, а тиме контрастивно и на поимање хетеротопичности, односно „измештености“ или „измишљености“ сликовитих исказа, тако и фикиионалности имаїинатиивних исказа делује на известан начин „повратно“на разумевање несликовитих исказа, на посебан начин „бојећи“ и „сенчећи“ њихову квазидискурзивност“ (Брајовић 2000: 186). 
тивних (у ширем смислу прозних), дескриптивних и поетских елемената. Другим речима, полазећи од хипотезе да је песму у прози у раној фази Кочићевог стваралаштва могуће тумачити као место сусрета различитих поетичких стратегија, преиспитујемо тезу о доминацији лирског начела која имплицитно оповргава хетерогену природу овог жанра. У аналитичком фокусу су текстови: Јелике и оморике, Кроз маїлу, Кроз свјеитлости, У маїли, Пјесма младости и, Јајие, који су излазили у току 1903. и 1904. године.

3.

Песма у прози Јелике и оморике објављена је у Срйском книжевном іласнику, (III/1903). У уводна два поглавља доминира дескриптивни тип исказа а песничке слике су засићене чулним утисцима, пре свега визуелним и колористичким („зелени кукуријек, плаве љубичице, бледуњавосвијетли пролетњи ваздух“), а потом аудитивним („цвркут птица“), олфактивним („мирис дријемовца“), тактилним („влажни пропланци“), или синестезијским („танки ваздух“). Флорални мотиви (љубичица, дријемовац, кукурек), као очекивани наставак онога што је насловом наговештено, изразито су антропоморфизовани при чему се персонификација и метафора јављају као кључни чиниоци аналогијске предикације песничке слике. Њен хетеротопијски и фикционални аспект интензивира се и персонификовањем фауне („њежно узбуђење птица“), али и других појава у природи („весели дим, весела свјетлост"). На плану жанровске изотопије прва половина текста активира иguлу као когнитивни (рецепцијски) генерички оквир којим се семантизује садејство дескриптивних и наративних исказа (буђење природе и промене у њој најављују долазак пролећа). Песничка слика отуд губи миметичка својства а референцијалност остаје на ниском степену базичне менталне схематизације. 
Чињеница да се поменута рецепцијска путања преусмерава унутар назначеног интерпретативног оквира потврђује правац симболизације песничке слике. Уместо са верном сликом природе, читалац се сусреће са њеним симболичким панданом а контраст којим почиње други део текста (тужна и ледена модрина јелове шуме) преозначава хетеротопијски аспект песничке слике. Јелике и оморике су симболични еквивалент лирског субјекта на шта експлицитно указује апострофирање („јелике моје и оморике“), те градирани прелаз дескриптивног у исповедни исказ („и мој је живот као и ваш пун њежне, дубоке чежње“). Даљој симболизацији доприноси и поистовећивање лирског субјекта исказа и лирског јунака, као и њихово синегдохијско преображавање на завршетку текста у неодређени колективни лик („чежња за вјечито зеленим прољећем које нам неће никада доћи“). Лирској експресивности, те идеолошком ангажману који се чита у симболичком кључу, доприноси и рефрен („срца пиште, нико их не чује; сузе теку, нико их не види“), као онај облик синтаксичког паралелизма карактеристичног за жанр песме у прози. ${ }^{6}$

Иако овај текст наглашене експресивне вредности говори о унутрашњем емоционалном и духовном стању субјекта исказа/јунака, он у свом заметку крије неко могуће збивање без чијег хипотетичног постојања предочено стање душе и пејзаж не би имали ту препо-

5 Мултипликација ауторске фигуре проистекле из полифоније гласова је још сложенија. Отуд је упутно говорити о инстанци апстрактног аутора, имплицитног аутора (лирског субјекта исказа), лирског јунака, али и о биографском аутору, чији се лик одражава као у огледалу у свим претходним. На то посебно упућује (ауто)биографски контекст Кочићевог дела, готово незаобилазан у тумачењу.

6 Детаљније о рефрену и ритмичкој прози видети у овде цитираној књизи Б. Стојановић Пантовић. 
знатљиву дозу трагизма, или обрисе људског лица. У патосу питања („Зашто је природа према њима, према мојим милим и драгим јеликама и оморикама, тако немилостива срца била?“), у метафори „следењених суза“, и слутњи „њежне чежње за вјечито зеленим прољећем које нам неће никада доћи!...", имплицитно су присутни још неки, периферни или удаљени светови, нешто што се већ догодило, али и нека, никад неостварена, виртуелна збивања. У ширем контексту модернистичке поетике, тај патос трагизма (често потенциран негацијама - „неће никад доћи“), ${ }^{7}$ потврђује припадност Кочићевих песама у прози општем духу времена и преовлађујућим поетичким стратегијама.

Закључак о хетерогеној природи поетске слике као динамичком имагинативу има своје упориште и на синтаксичкој равни. „Секвенцијалност“, као критеријум наративности у лирској песми (Хин 2016: 787), и у случају жанра песме у прози указује на то да она није лишена приче. У односу на оне видове поетичког дискурса који имају висок степен наративности, ${ }^{8}$ песма у прози, с обзиром на доминацију дескриптивних исказа, нема истакнут приповедни потенцијал, али није лишена догађајности. Категорију gоїђајносй овде преузимамо од В. Шмида који под тим подразумева „својство догађаја које подлеже градацији“ (Шмид 2016: 777). „По правилу, tellability (приповедни потенцијал, прим. C. М. М.) се подудара са догађајношћу у наративима са високим степеном овог својства, док се у наративима са ниском догађајношћу, или у онима који је готово не садрже, tellability може заснивати само на неостваривању очекиваног догађаја.“ (Шмид 2016: 777). Очито је, стога,

7 Сличан тон налазимо у раној прози В. Милићевића.

8 О условима наративности и њиховом степеновању в. Рајан: 2006: 8 . 
да Кочићеве ране прозе, не само да нису лишене приповедног, већ се и њихова актуелна манифестација у виду виртуелног наратива, заједно са стратегијама лиризације, савршено уклапала у доминантну наративну стратегију модернистичке прозе. ${ }^{9}$

4.

У дужој лирској прози Кроз маїлу наративни део је знатно развијенији. Приповедач је део приказаног света, тзв. хомодијегетички, и има статус сведока, посматрача. Почетак је сасвим уобичајен за уводни оквирни облик касног реалистичког проседеа.

„Изјахао сам наврх Кланца. Иза мене се, под блиједом, мутном свјетлошћу, шири Радмањско поље и сви брежуљци и равнице доље до Козаре, над којом се, као и обично у јесен, бијаху наднијели мрачни, згуснути, при дну загаситоплавичасти облаци.“

За разлику од претходне песме у прози чији је хронотоп обликован у симболистичком стилу, у овој краткој причи се јављају конкретни топоними (Кланац, Радманско поље, Козара), који доприносе „референцијалној илузији“, односно, лирској слици дају миметичку уверљивост. Почетак заплета је остварен увођењем динамичког мотива који подсећа на Лазаревићеву приповетку Ветиар: $:^{10}$ „Наједанпут снажно духну вјетар“, и који уводи у причу о растављеним љубавницима и трагичној судбини девојке. Као и Б. Станковић (лик Стојана

9 О природи и функцији виртуелног наратива као парадигми модернистичког приповедања у српској књижевности в. Милосављевић Милић 2016: 140.

10 Иако настала у периоду реализма, управо је ова Лазаревићева приповетка означила почетак симболизма у српској књижевности. 
у приповеци У ноћи), и Кочић у „неоромантичарском стилу“ (Вучковић 1996) јунака уводи песмом да би преко мотива тајне и фатума мистификовао збивање: („Кобна је то тајна.). “11 Даљем гранању сижеа и јачању степена „засићености“ света приче (Долежел 2008: 177) доприноси активирање познатог фолклорног мотива, топоса

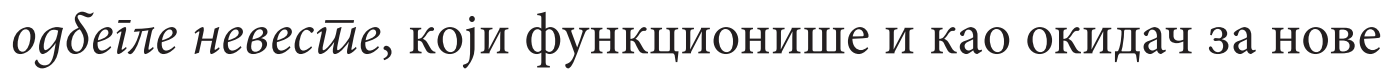
значењске варијације претходно поменутих мотива усуда и лудила. У лику несрећне Марушке Кочић спаја неколико поетичких линија: симболистичку (функционалан мотив магле), реалистичку (стварносна подлога, одлазак мушкараца у војну), која је допуњена антропогеографском мотивацијом („Од једне чудне и загонетне болести, која се ненадно појави, страдају планинска женска чељад.“) $)^{12}$ и фолклорну („Волим да ме бијесни вуци на комадиће истргају него да ме се његова рука дотакне!“), да би на завршетку приче поентирао у мелодраматичном тону („Изумрло, огољело трње око нас почиње се трести, дрхтати, савијати“) свеопштег удеса („спржене, голе равни, хладне и мртве, као блиједи, мртвачки образи“) који обухвата и самог приповедача („говорим ја, а снажни, бијесни вихор гуши ме, зауставља ми дисање“).

11 Кочић је и у публицистичким радовима понекад прибегавао истом поетском регистру као у фикционалним текстовима, када би писао о необичној, мистичној лепоти свога завичаја. То може

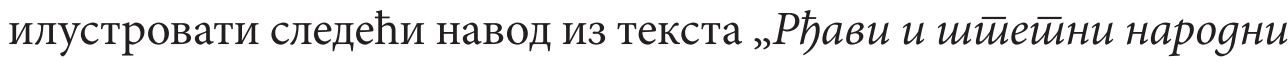
oбичаји“ (1912): „Као крупни и бјеличасти планински волови леже гомиле огромног четвртастог камења и, изложени погледима са свију страна, мирно се прелијевају у сунцу и почивају као у дубоком сну. И кад их човјек погледа, и нехотице га обузме осјећај језиве планинске мистике и побожности.“

12 У својим етнографским текстовима Кочић се на више места позива на истраживања Јована Цвијића из чега се може закључити да је писац високо ценио и уважавао рад нашег чувеног научника. Тако, на пример, у већ поменутом публицистичком тексту Кочић истиче да је антропогеографска истраживања свог родног краја Змијања спроводио по методама др Јована Цвијића. 
Наративни динамизам се овде постиже и перспективизацијом приче (увођењем казивача сведока, променом дискурзивног регистра), што је пример традиционалних конвенција из реалистичког наслеђа, поред фолклорних наративних матрица. Притом, већ поменути фолклорни топос смене годишњих/природних циклуса и у овој причи мотивише симболичка значења активирајући ону функцију симболичког исказа коју Ц. Тодоров назива унутрашњом. ${ }^{13}$

5.

Варијације истог сижеа налазимо и у краткој причи

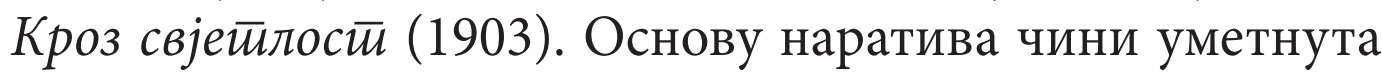
прича дата у ретроспективној техници сећања као садржај свести јунака. Тежиште је отуд на „личној мистици“ која прераста у „сугестивну недореченост и натчулну стварност“ (Пековић 1985: 548, 557): „Али силно осјећа да се нешто топло у њему диже, да му се нешто слатко и врело прелијева у души.“ Еротски мотиви овде подсећају на оне у Станковићевој прози, с тим што њихова читљивост код Кочића експлицитније зависи од (нео) романтичарских места или „имплицитних фолклорних знакова“ (Вукићевић 2006: 39): у овом случају реч је о мотиву уснуле драге и фаталне (неостварене) љубави. ${ }^{14}$ Иако је психонарација доминантан поступак, и овде је јунак својеврсни „медијум“ (Пековић 1985: 554), кроз који се прелама хронотопска и психолошка раван света

13 Према Тодорову, када је „симболички израз присутан зато што он не би моїао да то не буде“, ради се о унутрашњој функцији симболичког. Када „разлог за симбол почива у његовим учинцима“, у питању је спољашња функција симболичког израза (Тодоров 2010: 109).

14 Код оба писца јавља се исти модернистички топос виртуелног наратива када је реч о еротском. Песма у прози Кроз свјетилосии завршава се речима: „Он сав задрхта, занесе се у некакву чудновату земљу, пуну свјетлости, мириса и зеленила, у земљу гдје све примамљиво шуми, дрхће, стрепи.“ 
приче приближавајући симболички исказ „психолошкој фантастици“ (Пековић 1985: 554). Може се закључити да су у оним Кочићевим текстовима који су садржали већи степен догађајности и приповедног потенцијала песничке слике мање срасле са наративним секвенцама па је и мотивисаност симбола у овим имагинативима артифицијелнија.

6.

У краткој песми у прози У маїли (Политиика, 1904) садејство песничких слика и наратива остварује се путем већ уочених поступака; поново се јавља мултипликација и сажимање ауторске инстанце (лирски субјекат/ јунак), а исповедни тон мелодијским лирским регистром наткриљује наративни глас. Због вишеструких виртуелних микронаратива ни овај текст није лишен приповедног потенцијала, али се догађајност више заснива на генеричким интертекстуалним релацијама, него на збивањима у актуелном свету приче.

Потреба јунака за бекством кореспондира са алтернативним визијама бољег живота, у чему се препознаје још један фреквентни модернистички периферни наратив: „срце зажели да се уклони негдје далеко, далеко испод овог суморног, тешког неба“. Притом се фрагментарност приповедних секвенци мотивише сећањем (сусрет са Циганком), те је збивање у првом реду унутрашње, емоционално или психолошко: „ти се нећеш никад вратити у отаџбину, којој си све дао а она те је презрела и немилостиво одгурнула!"Етички и идеолошки ангажман унутар драмско-иконичког представљања проширен је алтернативном причом у чијој се основи препознаје архетипски наратив путовања у обећану земљу:

„тамо је земља, лијепа и добра земља која ће те раширених руку дочекати, јер и ти њу неизмјерно волиш и 
увијек о њој говориш и сањаш. Разведри се, јер путујемо у земљу снова твојих.“

Овој аркадијској слици супротстављена је негативна визија земље без будућности: „Намрачимо се и стегнимо срца, јер ћемо убрзо приспјети у земљу гдје ће нас дочекати мраз и сува, оштра зима са леденим, страховитим вјетровима и подмуклим бурама“. Антропоморфизоване слике природе, чија се симболика додатно ојачава контрастом, могу се овде повезати и са „спољашњом функцијом симболизације“ која се, према Ц. Тодорову, огледа у деловању на реципијента. Истовремено, пренаглашени патос ауторске интенције песничким сликама додељују ону улогу коју је критика препознала у феномену „антериорне нарације“ (Стојановић Пантовић 2001: 66) па се песма у прози, упркос свом жанровском херметизму, начелно може тумачити кроз поступке усклађивања и хомогенизација стилских и дискурзивних стратегија. То је и један од разлога за њено позиционирање унутар репрезентативних модернистичких жанрова.

7.

Наглашену артифицијелност симболичких песничких слика уочавамо у лирској прози метафоричног наслова Пјесма младостии (1904). Препознатљива атмосфера магле и визуелизација слике у импресионистичкој sfumato техници, мешање сна и јаве („Да ли је ово, друже, што ћу ти сад рећи била јава или сан, не знам.“), преплиће се са метафоричко-симболичким портретима па цела ова песма у прози постаје алегорија древног мотива прохујале младости. Посебну упечатљивост носи (нео) романтичарска слика белих кочија („кола бијела као снијег, са бијелим упрегнутим коњима“), са познатим романтичарским первертирањем девојке невесте у лик умрле драге, односно, антропоморфизоване смрти: 
„На њој бијаше све ново, бијело, чисто и миришљаво. На пуним њедрима, која су већ почела сахнути, стајала је прибодена велика јесенска ружа са потрганим увелим лишћем.“

И на примеру ове песме у прози може се уочити сва сложеност имагинатива као менталног конструкта песничке слике. И мада је тешко противречити ставу да „симбол носи увек нешто што се не може пренети на научни дискурзивни језик“ (Митровић 1985: 562), оно што се ипак преведе у интерпретативни дискурс настаје као резултат интеракције вишеструких инпута различитог порекла. Уз то, нема сумње да је крхка наративна матрица симболистичке прозе („знам да се скоро догодило, и да се догодило под позну, дубоку јесен на једном планинском друму“), нудила онај познати пут којим се чешће иде и лакше проходи кроз шуму симбола. Сложићемо се, стога, са Ц. Тодоровим који, сагледавајући тумачење као противтежу природи симболичке продукције, закључује да „ништа није лакше од симболизовања и тумачења, а ништа није произвољније од мотивисања.“ (Тодоров 2010: 116), јер „свака интерпретативна стратегија поступа одузимањем, а не збрајањем“ (Тодоров 2010: 116).

8.

Кратка песма у прози Јајце (1904), о којој ће још овде бити речи, разликује се од претходних по интензитету идеолошког ангажмана ауторског субјекта/јунака и по снажнијем упливу натуралистичких елемената у песничке слике. Конкретнији историјски контекст и са њим усаглашена хронотопизација (Босна, Јајце, Плива, кула Св. Луке) пресудни су за рецепцију менталне слике позадинског наратива. Њему припада и метонимијско издвајање „заборављених и несретних владара“, као и призори скелета „непослушних поданика и смјелих 
завереника“. Патос историјског страдања и носталгија за прошлим, за „минулом босанском снагом и моћи“, дају основни емоционални тон и наративу и песничким сликама. Услед специфичне природе овог топоса јака епска места као знаци текстуализације историје, добијају двоструко амблематичко и симболичко значење. У том фигуративном кључу може се читати и завршно поентирање у коме усуд страдања обједињује мистику и трагизам прошлог и садашњег доба.

У прилог прозирности симболичких слика у овом тексту иде и исповедни (аутобиографски) глас ${ }^{15}$ ауторског субјекта/јунака чији се идентитет успоставља управо на негацијама, што је блиско модернистичком растакању „наративног идентитета“, који овде узимамо у значењу које је том појму дао П. Рикер (1991: 73).

9.

У закључку бисмо могли сумирати основна својства кратке лирске прозе Петра Кочића. Песничке слике у њима настају сложеним садејством имагинатива и дискурзивних исказа (пре свега, наративних и дескриптивних текстова), а њихова хетерогена природа се додатно усложњава активирањем интертекстуалних (првенствено генеричких) образаца, као што су идила, одисејевски мотив, сиже поклоничког путовања, епско страдање. Интертекстуалну резонанцу као генератора рецепцијских схема имају и фолклорни предлошци (топоси и сижеи: отмица девојке, одбегла млада, присилна удаја).

15 Читању Кочићевих песама у прози у идеолошком и аутобиографском кључу увек је разлог налажен у ауторовом политичком деловању, али се веза између Кочићевих документарних и небелетристичких текстова и фикционалних, као што су његове песме у прози, такође може уочити на више места, као што су: идеолошка интенција, антропогеографска мотивација ликова, фикционализација и поетизација хронотопа, исповедни тон. 
Посебан облик фолклорне цитатности представља интерполирање стихова. Приметно је и интертекстуално деловање блиске традиције: романтичарске реминисценције ${ }^{16}$ (топоси умрле драге и херојске прошлости, мистификација природе), реалистичка мотивација и хронотопска номенклатура (ликови, просторно окружење). Док се лирска компонента ослања на фигуративни исказ (преовладавају персонификација, метафора, метонимија, емфаза и симбол), наратив песме у прози показује знатно динамичнију природу. Степен догађајности зависи од начина наративизације (јачања приповедног потенцијала), на једној страни и његове редукције, на другој страни. У првом случају се могу издвојити: 1) уметнути микро-наративи, техника флешбека; 2) жанр слике (кићење невесте); 3) преозначавање топоса (нпр. гротеском); 4) симболизација архетипског и фолклорног обрасца (природне мене, обнављање и рађање природе; 5) виртуелни наратив; 6) натурализација наративних фрагмената.

Као видове наративне редукције наводимо: 1) симболизацију лика (артифицијелност Марушкиног монолога); 2) амблематику лика-колектива (илустративни дијалог о судбини Марушке); 3) разбијање фикционалног оквира документарним дискурсом; 4) симболизација хронотопа, укидање конкретних тополошких атрибута на рачун лајтмотивских понављања призора, укидање ентеријера, отворени простор; 5) синхронизација приповедања/казивања и доживљаја. Према свим овим одликама Кочићеви текстови у време када су се јавили већ су били изданци модернизма, а оно што их је издвајало у уметничком погледу, у односу на исте жанровске појаве (нпр. песме у прози Дучића и Ускоковића), јесте, између осталог, свежина песничких слика и емоционални ангажман ауторског (лирског субјекта) гласа.

16 Р. Вучковић ихподводи под поетичкукатегоријунеоромантизма (Вучковић 1990). 


\section{0.}

Однос приче и симбола, те статус догађаја у контексту песничких слика, отвара начелно питање које се тиче стратегија модернистичког приповедања а на које овом приликом можемо указати само у грубим цртама. Наиме, уколико имамо у виду однос приповедног потенцијала и догађајности, а за примере узмемо једног од најбољих аутора кратке прозе, А. П. Чехова и нашег П. Кочића, у чијим поетикама долази до дезинтеграције реалистичке референцијалности, можемо закључити да код Чехова промена долази изнуйра захватајући сам свет приче (састављен неретко само од неостварених виртуелних могућности), ${ }^{17}$ док на нивоу формалних карактеристика исказа текст задржава традиционално приповедно излагање. ${ }^{18}$ У случају симболистичке прозе (као код Кочића), до промене долази сйоља, преко динамизације дискурса различитим типовима исказа, ${ }^{19}$ док се сам ментални чин креирања света приче као когнитивног оквира не доводи у питање, или се, штавише, учвршћује путем већ познатих „оквирних метаконцепата“ (Wolf 2006). На том трагу долазимо до претпоставке о два правца гранања модернистичке прозе на почетку 20. века - назовимо их овде, без претензија ка чврстим теоријским синтезама, $\bar{u} p a g u-$ иионални моgернизам и моgерна йраgиција. Можда након тога неће бити сасвим неупутно поставити и питање о разлици између канонских текстова, чија резонанца одзвања

17 Детаљније о томе у: Милосављевић Милић 2016: 129.

18 Ово се може односити и на ране назнаке модернизма у прози Лазе Лазаревића.

19 Са аспекта естетичких категорија овакав поступак, чији би парадигматичан еквивалент могла бити хетеротопичност песничке слике, може се повезати са тзв. „хиперкомпонентом“, модернистичким елементом који „нарушава класичну хармонију и потискује или истискује друге елементе из уметничког система“" (Борјев 2009: 319). 
у рецепцијској актуелности и данас и текстова обележених својом формалном иновативношћу који управо због тога остају заробљени у сопственој историчности.

\section{Извори и литература}

Bagić, K. Rječnik stilskih figura. Zagreb: Školska knjiga, 2012 Borjev, T. Estetika, (prev. R. Mečanin). Novi Sad: Prometej, 2009

Brajović, T. Teorija pesničke slike. Zavod za udžbenike i nastavna sredstva, 2000

Wolf, V. „Framing Borders in Frame Stories“. Eds. Werner Wolf and Walter Bernhart, Studies in Intermediality, 1. Framing Borders in Literatue and Other Media. Amsterdam:Rodopi, 2006

Вукићевић, Д. „Писмо и прича“. Кюижевности и језик. Београд: Чигоја, 2006

Vučković, Radovan. Moderna srpska proza. Beograd: Prosveta, 1990

Деретић, Јован. Истиорија срйске кюижевносиии. Београд: Нолит, 1983

Doležel, L. Heterokosmika, Fikcija i mogući svetovi. Beograd:

Službeni glasnik, 2008.

Дучић, Јован. Сабрана gела. Ваљево: Parnas Book, DLM, 2006

Кочић, Петар. Јајие, Сабрана gела I. Бањалука: Бесједа; Београд: Ars Libri, 2002

Кочић, Петар. Јелике и оморике, Сабрана дела I. Бањалука: Бесједа; Београд: Ars Libri, 2002

Кочић, Петар. Кроз маілл, Сабрана gела I. Бањалука: Бесједа; Београд: Ars Libri, 2002

Кочић, Петар. Кроз свјейлосй, Сабрана gела I. Бањалука: Бесједа; Београд: Ars Libri, 2002

Кочић, Петар. Пјесма млаgостич, Сабрана gела I. Бањалука: Бесједа; Београд: Ars Libri, 2002

Кочић, Петар. Рђави и шиетеини нарояни обичаји, Сабрана gела. Бањалука: Бесједа; Београд: Ars Libri, 2002

Кочић, Петар. У маіли, Сабрана gела I. Бањалука: Бесједа; Београд: Ars Libri, 2002

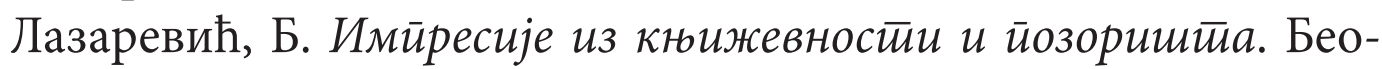
град: Завод за уџбенике и наставна средства, 2003 
Milosavljević Milić, Snežana. Virtuelni narativ - ogledi iz kognitivne naratologije. Sremski Karlovci - Novi Sad: Izdavačka knjižarnica Zorana Stojanovića; Niš: Filozofski fakultet, 2016

Митровић, М. „Размишљање о уметности као значењски слој прозе са почетка века“. Срйски симболизам, ииииолошка ироучавана. Београд: САНУ, 1985: 561- 573.

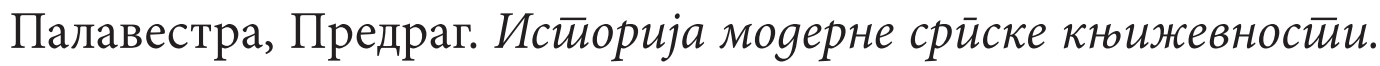
Београд: Књижевни гласник, 2013

Палавестра, Предраг. „Трајање, природа и препознавање српског симболизма“. Срйски симболизам, ииийолошка ироучавань. Београд: САНУ, 1985: 3-59.

Пековић, С. „Видови симболизма у српској прози почетком ХХ века“. Срйски симболизам, йийолошка йроучаваюьа. Београд: САНУ, 1985: 547-561.

Ryan, L. Avatars of Story. University of Minnesota Press, 2006

Recouer, P. „Narrative Identity”. Philosophy Today, 35:1 (1991: Spring): $73-81$.

Скерлић, Јован. Писии и књиіе , I. Београд: Завод за уџбенике и наставна средства, 2000

Стојановић Пантовић, Б. Срйске йрозаиgе, анйолоіија йесама у ирози. Београд: Нолит, 2001

Тодоров, Ц. Симболизам и йумачене. Београд: Службени гласник, 2010

Ulig, K. Teorija književne istorije. Beograd: Službeni glasnik, 2010

Хин, П. и Ј. Шенерт, „Теорија и методологија наратолошке анализе лирске поезије“. Philologia Mediana, VIII/8 (2016): 787-803

Шмид, В. „Догађајност, субјекат и контекст“. Philologia Mediana, VIII/8 (2016): 773-787. 
Snežana Milosavljević Milić

\section{THE POETICS OF LYRICAL PROSE PETAR KOČIĆ}

\section{Summary}

The paper discusses the poetic procedures of shorter prose texts by Petar Kočić announced in the magazine Serbian Literary Gazette and Journal of Politics during the 1903 and 1904: Christmas trees and spruces, Vaguely, Through the light, In the fog, Song of youth, Jajce. Attention is focused on those aspects of the text that recognize the new, modernist methods, such as the lyrical expression, narrative fragmentation, the primacy of description, erotic motifs. It points to the role of virtual narrative as distinctive modernist process that is associated with a different formatting characters, chronoscope and author of the subject, than was the case in the past, a realistic period. As a paradigmatic isolated motif mist that carries multiple symbolic and (auto) poetic meanings. Within the context of contemporary methodological trans medial and cognitive narratology to analyze the phenomenon of genre hybridity mentioned prose texts.

Key words: poem in prose, modernism, symbolism, narrative, poetic pictures. 